\author{
Contents list available at Multidisciplinary Journal website \\ Multidisciplinary Journal \\ Journal homepage: https://jurnal.unej.ac.id/index.php/multijournal
}

\title{
Ketersediaan Tenaga Kesehatan Promotif dan Preventif Puskesmas di Kabupaten Jember
}

\author{
Availability of Promotive and Preventive health services for Public Health Centers in Jember \\ District
}

\author{
Rizkiy Shofiah ${ }^{1}$, Dewi Prihatini ${ }^{2}$, Sebastiana Viphindartin ${ }^{3}$ \\ ${ }^{1}$ Mahasiswa Pascasarjana Ilmu Kesehatan Masyarakat Universitas Jember ${ }^{2}$ Program Studi Ilmu Manajemen Univeristas Jember \\ 3 Program Studi Ilmu Ekonomi Pembangunan \\ Email: rizkiyshofiah704@gmail.com
}

\begin{abstract}
Community Health service is the first level facility which enables promotive and preventive service to gain health. The administration of health service should be supported by qualified medical workers to support the function of community health service. Concerrning its function, the service is required to have at least five promotive and preventive workers including laboratory analyst, nutritionist, public health workers, and sanitary worker. The availability of medical human resources in Community Health service has not yet distributed evenly in Jember Regency. The recruitment of the health human resources in Jember still focuses on medical workers This research is a descriptive research using qualitative approach aiming at describing the availability of promotive and preventive workers in Community health service in Jember regency based on Minimum Resources Standard. The findings shows that out of 50 Health service 30 of them do not have analyst , 28 without nutritionist, 37 with no public health workers and 36 without sanitation workers , as shown by data from Health Office. The informant reveals that the uneven distribution of promotive and primitive workers is caused by (1) Health office zero recruitment for Health service, (2) the policy restriction for health service for utrititonist, (3) the limit of Health service budget for the recruitment.
\end{abstract}

Keyword: the availability, promotive and preventive workers, community health service

ABSTRAK. Puskesmas merupakan fasilitas tingkat pertama yang mengupayakan pelayanan promotif dan preventif untuk mencapai derajat kesehatan. Penyelenggaraan pelayanan kesehatan harus didukung oleh tenaga kesehatan yang memadai untuk menunjang fungsi puskesmas. Sesuai dengan fungsinya puskesmas wajib memiliki minimal lima tenaga promotif dan preventif diantaranya yaitu tenaga analis laboratorium, tenaga gizi, tenaga kesehatan masyarakat, dan tenaga sanitasi. Ketersediaan sumber daya manusia kesehatan (SDMK) puskesmas khususnya keempat tenaga promotif dan preventif ini masih belum merata di puskesmas Kabupaten Jember.Perencanaan SDMKdi Kabupaten Jember masih berfokus pada tenaga medis. Penelitian ini merupakan penelitian jenis penelitian deskriptif dengan pendekatan kualitatif yang bertujuan untuk menggambarkan ketersediaan tenaga promotif dan preventif puskesmas di Kabupaten Jember berdasarkan Standar Ketenagaan Minimal (SKM). Hasil penelitian menunjukkan, berdasarkan data dari Dinas Kesehatan menunjukkan dari total 50 puskesmas, sebanyak 30 puskesmas belum memiliki tenaga analis, 28 puskesmas belum memiliki tenaga gizi, 37 puskesmas belum memiliki tenaga kesehatan masyarakat, dan 36 puskesmas belum memiliki tenaga sanitasi. Berdasarkan informasi yang diperoleh dari informan penelitian ada beberapa halyangmenyebabkan ketersediaan tenagapromotifdan preventifdipuskesmasbelummerata. Pertama, tidakada rekrutandari Dinas kesehatan untukpuskesmas. Kedua, keterbatasan puskesmas karena kebijakan yang berlaku sehingga menghambat dalam proses pemenuhan kebutuhan tenaga gizi. Ketiga, keterbatasan anggaran puskesmas sehingga tidak bisa melakukan rekrutan.

Kata Kunci: Ketersedian, tenaga promotif, preventif, puskesmas

\section{Pendahuluan}

Sumber Daya Manusia Kesehatan (SDMK) merupakan salah satu bagian penting dalam upaya peningkatan kesejahteraan dan kesehatan masyarakat di Indonesia. SDMK merupakan ujung tombak dalam pelayanan kesehatan baik preventif, promotif, kuratif, dan rehabilitative. Puskesmas merupakan Fasilitas Pelayanan
Tingkat Pertama (FKTP) yang menyelenggarakan upaya kesehatan masyarakat dan perseorangan serta lebih mengutamakan upaya promotif dan preventif untuk mencapai derajat kesehatan setinggi - tingginya. Pasal 1 ayat 2 PMK No 75 tahun 2014 juga dijelaskan bahwa fungsi puskesmas lebih mengutamakan upaya promotif dan preventif untuk mencapai derajat kesehatan masyarakat. Peraturan Menteri Kesehatan No 75 tahun 2014 tentang 
Pusat Kesehatan Masyarakat menyebutkan puskesmas minimal memiliki 5 jenis tenaga kesehatan promotif dan preventif dan empat diantaranya diantaranya yaitu tenaga analis laboratorium, tenaga gizi, tenaga kesehatan masyarakat, dan tenaga sanitasi.

Berdasarkan data Dinas Kesehatan Kabupaten Jember tahun 2016 menunjukkan bahwa distribusi tenaga kesehatan belum merata terutama untuk tenaga promotif dan preventif puskesmas. Hal tersebut karena keterbatasan tenaga dan perencanaan SDMK Puskesmas di Kabupaten Jember masih berfokus pada pemenuhan tenaga medis. Kabupaten Jember memiliki 50 puskesmas dan data dari Dinas Kesehatan menunjukkan sebagian besar puskesmas belum memiliki tenaga analis laboratorium, gizi, kesehatan masyarakat, dan sanitasi.

Keberadaan emapt tenaga tersebut sangat penting untuk menunjang fungsi puskesmas sebagai promotif dan preventif. Dalam Permenkes No 75 tahun 2014 tentang puskesmas dijelaskan tentang Standar Ketenagaan Minimal (SKM) tenaga kesehatan termasuk standar tenaga analis, gizi, kesehatan masyarakat, dan sanitasi. Setiap puskesmas memiliki kebutuhan yang berbeda antara rawat inap dan non rawat inap. Penelitian ini bertujuan untuk mengetahui ketersediaan tenaga analis, gizi, kesehatan masyarakat, dan sanitasi puskesmas berdasarkan Standar Ketenagaan Minimal (SKM). Metode SKM merupakan salah satu metode paling sederhana yang digunakan untuk mengetahui kebutuhan SDMK puskesmas. Metode SKM tercantum dalam Permenkes No 75 tahun 2014 dan Permenkes No 33 tahun 2015, sehingga dalam penelitian ini memilih menggunakan metode SKM sebagai acuan dalam menentukan kebutuhan SDMK puskesmas.

\section{Metode Penelitian}

Penelitian ini merupakan penelitian deskriptif dengan pendekatan kualitatif yang bertujuan untuk menggambarkan ketersediaan tenaga promotif dan preventif puskesmas di Kabupaten Jember. Penelitian ini dilakukan di Puskesmas Kabupaten Jember. Informan dalam penelitian ini yaitu petugas analis laboratorium, gizi, kesehatan masyarakat, dan sanitasi.

\section{Hasil dan Pembahasan}

Data hasil rekapitulasi ketersediaan tenaga preventif dan promotif puskesmas di Kabupaten Jember menunjukkan bahwa sebagian besar puskesmas belum memiliki tenaga promotif dan preventif. Berikut ini merupakan jumlah puskesmas yang belum memiliki tenaga analis, gizi, kesehatan masyarakat, dan sanitasi.

Tabel 1. Kebutuhan Tenaga Gizi Puskesmas

\begin{tabular}{lc}
\hline \multicolumn{1}{c}{ Jenis Tenaga } & $\begin{array}{c}\text { Jumlah Puskesmas yang belum } \\
\text { memiliki }\end{array}$ \\
\hline Analis Laboratorium & 32 puskesmas \\
\hline Gizi & 28 puskesmas \\
\hline Kesehatan Masyarakat & 37 puskesmas \\
\hline Sanitasi & 36 puskesmas \\
\hline
\end{tabular}

Tabel 1 merupakan rekapitulasi jumlah puskesmas di Kabupaten Jember yang belum memiliki tenaga analis laboratorium, gizi, kesehatan masyarakat, dan sanitasi. Kabupaten Jember memiliki 50 puskesmas, itu artinya sebagian besar puskesmas belum memiliki tenaga promotif dan preventif.

Permenkes No 75 tahun 2014 pasal 1 ayat 2 menjelaskan bahwa fungsi puskesmas lebih mengutamakan upaya promotif dan preventif untu mencapai derajat kesehatan masyarakat. Namun, pada kenyataannya sebagian bersar puskesmas belum memiliki tenaga promotif dan preventif sesuai standar Permenkes. Informasi yang diperoleh dari informan di puskesmas menjelaskan bahwa tugas promotif dan preventif dilaksanakan oleh petugas medis seperti bidan atau perawat. Hal tersebut tentu akan menyebabkan beban kerja bertambah atau double job pada tenaga medis.

Akses masyarakat terhadap layanan kesehatan sudah mengalami peningkatan. Puskesmas sebagai fasilitas kesehatan tingkat pertama pada era Jaminan Kesehatan Nasional (JKN) ini tentu mengalami peningkatan jumlah kunjungan pasien. Hal ini tentu saja menyebabkan ketimpangan antara jumlah kunjungan pasien yang semakin bertambah dengan SDMK yang tersedia di puskesmas. Kementerian Kesehatan juga menyampaikan adanya ketimpangan dalam penyebaran tenaga kesehatan sesuai jenis dan sifat pekerjaannya (). Hal tersebut juga dijelaskan dalam penelitian Mujiati dan Yuyun (2016) yang menyatkan bahwa ketersediaan SDMK pada masing - masing FKTP belum merata ketersediaannya. SDMK yang belum merata di beberapa puskesmas ini menjadi permasalahan yang harus segera ditangani. Puskesmas di Kabupaten Jember sebagian besar masih memiliki tenaga medis (dokter, dokter gigi, perawat, bidan).

Puskesmas terdiri dari rawat inap dan non rawat inap. Dalam Permenkes No 75 tahun 2014 disebutkan bahwa karakteristik puskesmas terdiri dari puskesmas pedesaan, pesisir, dan perkotaan yang memiliki standar ketenagaan yang berbeda sesuai karakteristik daerah masing - masing. Tabel 2 dibawah ini merupakan gambaran standar ketenagaan minimal yang harus dimiliki puskesmas.

Tabel 2. Standar Ketenagaan Minimal Puskesmas

\begin{tabular}{|c|c|c|}
\hline Jenis Tenaga & Rawat Inap & Non Rawat Inap \\
\hline \multicolumn{3}{|c|}{ Puskesmas Pedesaan } \\
\hline 1. Analis & 1 & 1 \\
\hline 2. Gizi & 2 & 1 \\
\hline 3. Kesmas & 1 & 1 \\
\hline 4. $\quad$ Sanitasi & 1 & 1 \\
\hline \multicolumn{3}{|l|}{ Puskesmas Pesisir } \\
\hline 1. Analis & 1 & 1 \\
\hline 2. Gizi & 2 & 1 \\
\hline 3. Kesmas & 1 & 1 \\
\hline 4. Sanitasi & 1 & 1 \\
\hline \multicolumn{3}{|c|}{ Puskesmas Perkotaan } \\
\hline 1. Analis & 1 & 1 \\
\hline 2. Gizi & 2 & 1 \\
\hline 3. Kesmas & 2 & 2 \\
\hline
\end{tabular}


4. Sanitasi 1 1

\section{Puskesmas Pedesaan}

Puskesmas merupakan salah satu pelayanan kesehatan di area pedesaan dimana karakteristik wilayahnya berbeda dengan puskesmas pesisir dan perkotaan. Puskesmas rawat inap idealnya memiliki satu tenaga analis laboratorium, dua tenaga gizi, satu tenaga kesehatan masyarakat, dan satu tenaga sanitasi. Sedangkan untuk non rawat inap masing - masing membutuhkan satu tenaga. Namun, dibeberapa puskesmas pedesaan yang ada di Kabupaten Jember sampai saat ini keberadaan tenaga promotif dan preventif masih langka. Hal tersebut menyebabkan tugas - tugas terkait gizi, analis, sanitasi atau promosi kesehatan pada akhirnya dilaksanakan oleh perawat atau bidan yang ada di puskesmas tersebut.

Kurangnya tenaga ini berdampak pula pada beban kerja pegawai menjadi lebih berat atau terjadi double job dan berdampak pada pelayanan kesehatan yang kurang maksimal. Menurut Prasista (2017) rangkap jabatan bisa menimbulkan hambatan dalam kinerja karyawan.

\section{Puskesmas Pesisir}

Puskesmas berbeda dengan puskesmas di daerah pedesaan dan perkotaan yang ada di Kabupaten Jember. Salah satu contoh puskesmas daerah pesisir yaitu Puskesmas Puger dimana untuk pelayanan laboratorium lebih lengkap. Hal tersebut tentu membuat beban kerja antara tenaga analis puskesmas pedesaan atau perkotaan berbeda dengan puskesmas pesisir. Pelayanan yang dilakukan meliputi pelayanan pasien rawat inap, rawat jalan, pasien KIA, dan pemeriksaan tambahan seperti IMS yang rutin dilakukan setiap satu sampai dua kali dalam seminggu. Selain sasaran pelayanan yang lebih banyak, jenis pemeriksaan juga lebih lengkap dibandingkan puskesmas wilayah pedesaan dan perkotaan. Puskesmas Puger memiliki dua tenaga analis laboratorium, namun dari hasil hasil wawancara dengan informan mereka masih mengharapkan Dinas Kesehatan bisa memberi tambahan tenaga. Pelayanan kesehatan yang berakitan dengan analis laboratorium yang kebih lengkap juga menggambarkan masalah kesehatan yang ada di wilayah Puskesmas lebih komplit.

Selain tenaga analis, keberadaan tenaga gizi dan promosi kesehatan atau tenaga SKM juga terbatas keberadaannya di puskesmas pesisir. Puskesmas Puger dan Wuluhan merupakan gambaran puskesmas pesisir yang tidak memiliki tenaga gizi. Pelayanan gizi di Puskesmas Puger dilaksanakan oleh bidan coordinator puskesmas dan hanya berfokus pada gizi masyarakat saja. Dalam Permenkes No 75 tahun 2014, idealnya puskesmas rawat inap memiliki 2 tenaga gizi, yaitu gizi klinik dan gizi masyarakat.

\section{Puskesmas Perkotaan}

Puskesmas area perkotaan merupakan puskesmas dengan wilayah kerja dan jumlah penduduk paling padat disbanding puskesmas pedesaan dan pesisir. Puskesmas Sumbersari merupakan salah satu puskesmas area kota yang memiliki pelayanan laboratorium yang lebih sedikit dibandingkan puskesmas pedesaan dan pesisir. Hal tersebut karenadi daerah perkotaan ada laboratorium swasta yang bekerja sama dengan puskesmas untuk melayani pasien rawat inap. Sedangkan puskesmas hanya melayani pasien rawat jalan dan pasien dari KIA.

Laboratorium puskesmas adalah sarana pelayanan kesehatan di puskesmas yang melaksanakan pengukuran, penetapan, dan pengujian terhadap bahan yang berasal dari manusia untuk penentuan jenis penyakit, penyebaran penyakit, kondisi kesehatan, atau faktor yang dapat berpengaruh pada kesehatan perorangan dan masyarakat (Permenkes No 37, 2012). Keberadaan tenaga analis laboratorium di puskesmas sangat penting untuk menunjang fungsi puskesmas berupa promotif dan preventif. Selain itu untuk menunjang program pelayanan kesehatan lainnya seperti pemeriksaan ibu hamil yang didalamnya wajib melakukan pemriksaan laboratorium lengkap untuk deteksi dini ibu hamil. Begitu juga dengan pelayanan TB, pelayanan IMS, dan pelayanan di poli rawat jalan ataupun rawat inap yang juga memerlukan kolaborasi dengan analis laboratorium. Puskesmas sebagai fasilitas kesehatan tingkat pertama perlu dilengkapi dengan laboratorium.

Pelayanan gizi di puskesmas terbagi menjadi dua untuk rawat inap, yaitu gizi klinik dan gizi masyarakat. Pelaksana UKM gizi bagi puskesmas yang belum memiliki tenaga gizi dilaksanakan oleh bidan. Apabila tim medis juga merangkap untuk melaksanakan tugas sebagai tenaga gizi, analis, kesehatan masyarakat, dan sanitasi maka akan mempengaruhi pelayanan tidak maksimal. Sejalan dengan penelitian Prasista (2017) yang menjelaskan bahwa rangkap jabatan menjadikan adanya benturan kepentingan. Double job juga terjadi pada pelayanan promosi kesehatan dan sanitasi yang seharusnya menjadi tanggung jawab tenaga kesehatan masyarakat dan sanitarian.

Keterbatasan tenaga promotif dan preventif puskesmas di Kabupaten Jember disebabkan oleh beberapa faktor. Dari hasil informasi yang diperoleh dari informan faktor tersebut diantaranya:

\section{A. Tidak ada rekrutan dari Dinas Kesehatan}

Dari hasil wawancara dengan informan, menyatakan bahwa salah satu faktor utama penyebab keterbatasan tenaga di puskesmas yaitu tidak ada rekrutan dari pihak puskesmas ataupun Dinas Kesehatan untuk tenaga promotif dan preventif. Kebijakan yang berlaku untuk puskesmas di Kabupaten Jember menjadi salah satu kendala dalam proses rekrutan. Keterbasan kapasitas puskesmas tidak bisa memenuhi kebutuhan tenaganya. Proses rekrutan di puskesmas harus melalui Dinas Kesehatan, sedangkan berdasarkan pernyataan informan tidak ada lowongan atau rekrutan dari Dinas Kesehatan.

Pihak puskesmas telah mengajukan kebutuhan tenaga kepada Dinas Kesehatan, akan tetapi proses tersebut 
harus menunggu lama untuk diimplementasikan. Hal tersebut menyebabkan puskesmas hanya bisa memaksimalkan dengan menggunakan tenaga seadanya, walaupun terjadi double job antar tenaga yang lainnya. Jika mengacu pada Permenkes No 33 tahun 2015 tentang pedoman penyusunan SDMK dijelaskan bahwa metode atau alat ukur yang bisa digunakan diantaranya telah menetapkan berbagai macam metode atau alat ukur diantaranya standar ketenagaan minimal (SKM), analisis beban kerja kesehatan (ABK kes), dan metode rasio penduduk.

\section{Terikat oleh kebijakan}

Puskesmas sebagai pelaksana hanya bisa menerima kebijakan yang berlaku saat ini. Kebijakan yang mengikat untuk tidak melakukan perekrutan teanaga dalam bentuk apapun. Kebijakan tersebut menyebabkan pihak puskesmas tidak bisa memberyakan dirinya dengan maksimal terutama dalam hal pengadaan atau perekrutan SDMK sesuai kebutuhan instansinya. Proses perencanaan dan perekrutan hanya dilakukan oleh Dinas Kesehatan. Walau implementasinya cukup lambat. Hasil penelitian Marlinda (2011) mengemukakan hal yang sama bahwa sistem perencanaan belum berjalan dengan baik disebabkan karena kurang lengkapnya data yang tersedia dan data yang ada tidak akurat, kurangnya sosialisasi dan informasi tentang kebijakan yang digunakan dalam perencanaan tenaga kesehatan serta konsultasi dan koordinasi yang kurang baik.

\section{Keterbatasan Anggaran Puskesmas}

Insentif atau upah merupakan hak karyawan atau staf sebuah instansi yang diperoleh sebagai timbal balik atas kinerjanya. Hasil wawancara dengan informan, menyatakan bahwa sebagian besar dari tenaga analis mempertimbangkan untuk bekerja di puskesmas. Hal ini karena insentif yang diperoleh lebih kecil atau bahkan tidak menerima insentif. Puskesmas tidak memiliki anggaran untuk memberi gaji pada tenaga tidak tetap, sehingga mereka hanya bisa menggantungkan pada perolehan jasa pelayanan BPJS. Namun, untuk bisa mendapatkan japel tersebut harus memiliki SK dari Dinas Kesehatan.

Proses untuk mendapatkan SK dari Dinas Kesehatan tidaklah mudah. Hal tersebut menyebabkan tenaga yang ada di puskesmas akhirnya tidak mendapatkan insentif dan tentu menjadi pertimbangan bagi tenaga analis untuk bekerja di puskesmas. Berdasarkan penelitian terdahulu insentif dapat meningkatkan kinerja dan motivasi kerja karyawan atau staf dalam sebuah instansi.

\section{Kesimpulan}

1. Dari total 50 puskesmas di Kabupaten Jember, sebanyak 30 puskesmas belum memiliki tenaga analis, 28 puskesmas belum memiliki tenaga gizi, 37 puskesmas belum memiliki tenaga kesehatan masyarakat, dan 36 puskesmas belum memiliki tenaga sanitasi.

2. Jenis pelayanan yang dilaksanakan di puskesmas pedesaan, pesisir, perkotaan berbeda menyesuaikan dengan karakteristik wilayah masing - masing. Puskesmas pesisir memiliki pelayanan yang lebih komplek dibandingkan puskesmas pedesaan dan perkotaan.

3. Ada beberapa faktor yang menyebabkan tenaga promotif dan preventif ketersediaannya belum merata di puskesmas. Faktor penyebab tersebut diantaranya yaitu:
a. Tidak ada rekrutan dari Dinas Kesehatan
b. Terikat oleh kebijakan
c. Keterbatasan anggaran puskesmas

\section{Ucapan Terima Kasih}

Ucapan terima kasih kepada pihak - pihak yang telah berkontribusi dalam pelaksanaan penelitian ini:

1. Dinas Kesehatan Kabupaten Jember

2. Responden atau informan di Puskesmas Silo 2, Puger, dan Sumbersari.

3. Teman - teman yang telah membantu dalam proses penelitian.

\section{Referensi}

[1] Arifudin. S. Andri, M. 2017. Evaluasi Sistem Manajemen Sumber Daya Manusia pada Penempatan Kerja Petugas di UPT Puskesmas Lembasada. Promotif, Vol.7 No.1, Juli 2017 Hal 1-14.

[2] Benhard R. L. Paruntu A. J. M. Rattu C. R. Tilaar. 2015. Human Resource Requirements Planning in Health Center Minahasa District. JIKMU. Vol. 5, No. 1, Januari 2015

[3] Fitriah, Nurul. M. Zulkarnain. M. Husni Thamrin. 2016. Analisis Kebutuhan Psikiater Berdasarkan Beban Kerja dengan Menggunakan Metode Workload Indicator Staffing Needs (WISN) di Unit Rawat Jalan Jiwa RUmah Sakit Ernaldi Bahar Provinsi Sumatera Utara. Jurnal Kedokteran dan Kesehatan, Volume 3, No. 1, Januari 2016: 347-353

[4] Grace A. Salamate, A. J. M. Rattu, J. N. Pangemanan. 2014. Planning Analysis of Health Human Resource in Health Office Southeast Minahasa District. JIKMU, Suplemen Vol. 4, No. 4, Oktober 2014

[5] Pebriana Marlinda. (2017). Analisis Perencanaan Kebutuhan Tenaga Dokter oleh Dinas Kesehatan Kota Pekanbaru. Jurnal Niara Vol 9 No 2 Januari 2017

[6] M.Ikhsan,. M. Alwi,. Ridwan M. (2017). Peta Kebutuhan Dokter Umum Berdasarkan Beban Kerja untuk Mencapai Derajat Pelayanan Kesehatan yang Optimal di Puskesmas se-Kabupaten Muna. JST Kesehatan, Juli 2017, Vol. 7 No. 3 : $291-298$

[7] Nafizta R., Putri A., Ayun S. (2017). Analisis Beban Kerja dan Kebutuhan Tenaga Perawat di Puskesmas Poncol Kota Semarang. Jurnal Kesehatan Masyarakat (e-Journal), Volume 5, Nomor 3, Juli 2017 (ISSN: 2356-3346)

[8] Permenkes RI No 75. (2014). Peraturan Menteri Kesehatan Nomor 75 tahun 2014 tentang Pusat Kesehatan Masyarakat. Jakarta: Kementerian Kesehatan Republik Indonesia. 
[9] Permenkes RI No 37. (2012). Penyelenggaraan Laboratorium Pusat Kesehatan Masyarakat. Jakarta: Kementerian Kesehatan Republik Indonesia.

[10] Permenkes RI No 33. (2015). Penyusunan Perencanaan Kebutuhan Sumber Daya Manusia Kesehatan. Jakarta: Kementerian Kesehatan Republik Indonesia.

[11] Prasista., B., A. Yuniarta G., A., dan Wahyuni, M., A. 2017. Analisis Efektifitas dan dampak rangkap jabatan dalam peningkatan kinerja organisasi PT. Harta Ajeg Lestari, di Kelurahan Banyuning Kecamatan Buleleng. Jurnal Sl Ak, Universitas Pendidikan Ganesha, 8(2):1-10

[12] Putri, Aragar. 2017. Kesiapan Sumber Daya Manusia Kesehatan dalam Menghadapi Masyarakat Ekonomi Asean (MEA). Jurnal Medicoeticolegal dan Manajemen Rumah Sakit, 6 (1): 55-60, Januari 2017

[13] Teti S., Sukri P., Arifin S. (2017). The Needs of Nurse at Public Health Center in South Buton Regency, Indonesia. International Journal of Sciences: Basic and Applied Research (IJSBAR) (2017) Volume 34, No 3, pp 309-321

[14] Triyanik dan Bambang B. (2018). Kebutuhan Tenaga Klinik Sanitasi dengan Metode Workload Indicators Of Staffing Needs. Journal Unnes, HIGEIA 2 (1) (2018)

[15] Yuyun dan Mujiati. (2016). Ketersediaan Sumber Daya Manusia Kesehatan pada Fasilitas Kesehatan Tingkat Pertama dalam Era Jaminan Kesehatan Nasional di Delapan Kabupaten - Kota di Indonesia. Jakarta: jurnal Media Litbangkes, Vol. 26 No. 4, Desember 2016, 201-210 